\title{
Assessing land cover change in Namibia's Kavango East region: a multi-date object approach
}

\author{
Edward MUHOKO ${ }^{1,2}$ \\ Carlos DE WASSEIGE 3,4 \\ Vera DE CAUWER ${ }^{5}$
}

${ }^{1}$ Ministry of Environment, Forestry

and Tourism

Directorate of Forestry

Private Bag 13306, Windhoek, Namibia

2 University of Bayreuth

Bayreuth Center of Ecology

and Environmental Research (BayCEER)

Department of Plant Ecology

Universitätsstrasse 30

95447 Bayreuth, Germany

${ }^{3}$ Namibia University of Science and Technology

Department Geo-Spatial Sciences and Technology

Private Bag 13388, Windhoek, Namibia

${ }^{4}$ Systèmes d'information à référence spatiale (SIRS)

27, rue du Carrousel, Parc de la Cimaise 59650 Villeneuve-d’Asq, France

${ }^{5}$ Namibia University of Science and Technology

Department Agriculture and Natural

Resources Sciences

Private Bag 13388, Windhoek, Namibia

\section{Auteur correspondant /}

Corresponding author:

Edward Muhoko -

Edward.Muhoko@uni-bayreuth.de

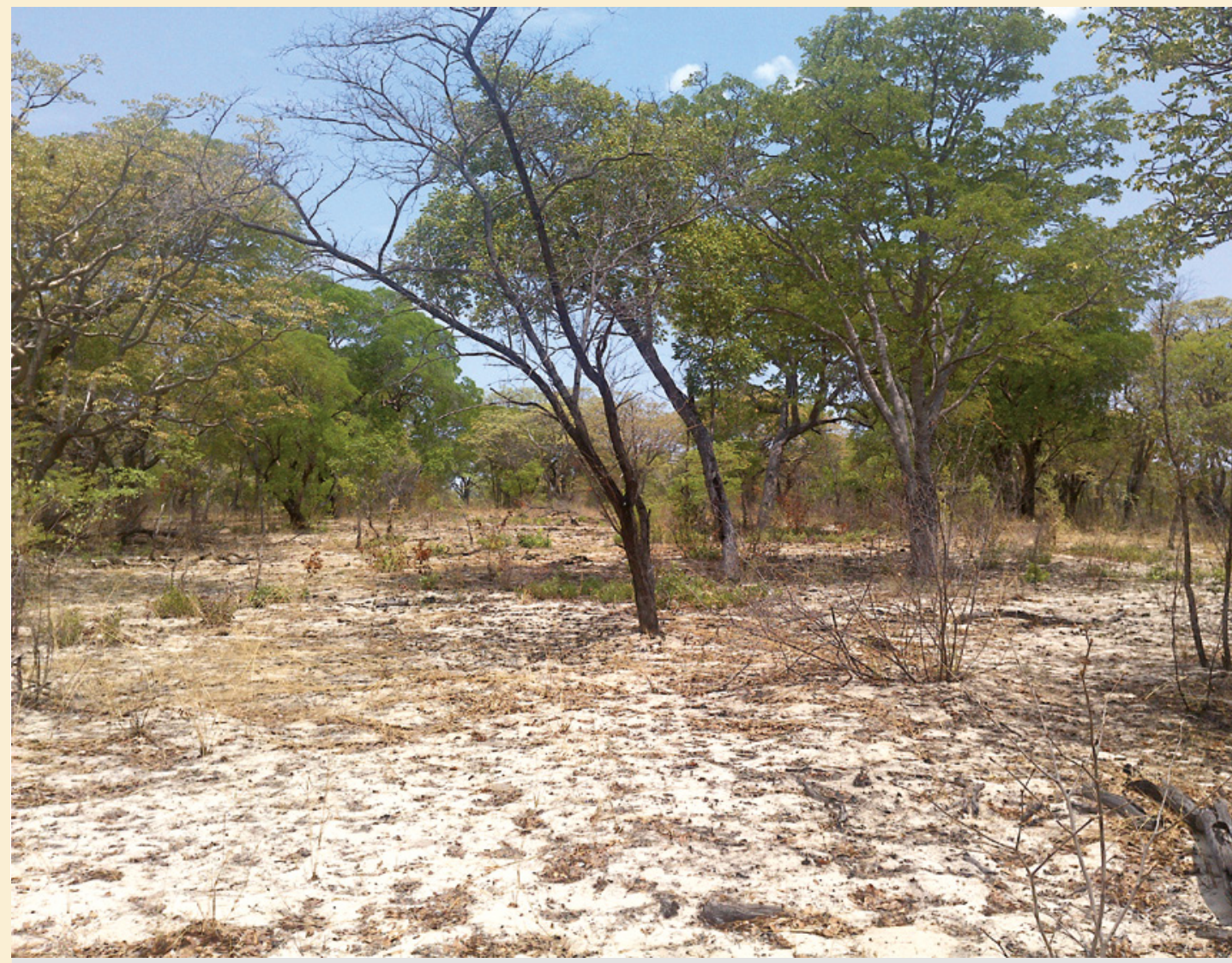

Photo 1.

The forest stand is part of the broad-leafed savanna biome of the Kavango East region, Namibia. Photo E. Muhoko.

Doi : 10.19182/bft2020.344.a31897 - Droit d'auteur (C) 2020, Bois et Forêts des Tropiques @ Cirad - Date de soumission : 8 juillet 2019 ; date d'acceptation : 24 avril 2020 ; date de publication : $1^{\text {er }}$ juin 2020.

\section{(2:) Cirad (ain}

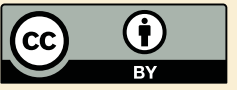

Citer l'article / To cite the article

Muhoko E., de Wasseige C., De Cauwer V., 2020. Assessing land cover change in Namibia's Kavango East region: a multi-date object approach. Bois et Forêts des Tropiques, 344: 17-32. Doi: https://doi.org/10.19182/bft2020.344.a31897 


\section{RÉSUMÉ}

\section{Évaluation des modifications de l'occupation des sols dans l'Est-Kavango en Namibie selon une approche multi- dates par objet}

Les modifications de l'occupation des sols représentent une problématique mondiale, mais leurs effets peuvent être particulièrement sévères dans les pays en développement comme la Namibie, où elles perturbent le fonctionnement des écosystèmes et, de ce fait, la soutenabilité du développement économique. Les conditions arides en Namibie, dues à la faible pluviométrie et aux taux élevés d'évapotranspiration, amplifiées par les feux de brousse qui sévissent chaque année, se traduisent par un paysage hétérogène caractérisé par un mélange d'arbres, d'arbustes et de plantes herbacées. De ce fait, les cartes d'occupation des sols sont souvent imprécises à l'échelle du pixel. Cependant, et malgré leur précision relativement élevée, l'analyse d'images par objets est encore loin d'être largement utilisée pour les forêts tropicales sèches de l'Afrique australe. Cette étude vise à évaluer les modifications de l'occupation des sols selon une approche multi-dates par l'objet, afin d'en déterminer l'ampleur et la dynamique dans ce paysage hétérogène de l'Est-Kavango, région de Namibie où le couvert végétal est parmi les plus denses. La segmentation multi-dates, les valeurs moyennes des courbes et la différenciation des images ont permis de détecter les modifications de l'occupation des sols sur quatre périodes (1990, 2000, 2009 et 2016). Pour toutes les périodes, la modification la plus fréquente est la conversion de forêts en terres agricoles. En 1990, les forêts recouvraient $58 \%$ des terres de l'étude pour $55 \%$ en 2016, tandis que, sur la même période, la superficie des terres agricoles doublait, passant de $3 \%$ en 1990 à $6 \%$ en 2016. Les résultats obtenus par l'approche novatrice adoptée pour cette étude sont prometteurs en comparaison des méthodes traditionnelles, où la détection de modifications postérieures au classement peut être erronée. La méthode utilisée peut donc être recommandée pour le suivi à long terme des modifications de l'occupation et l'utilisation des sols dans les zones caractérisées par des conditions environnementales biophysiques similaires.

Mots-clés : période, modification de l'occupation des sols, classification de l'occupation des sols, Landsat, segmentation multi-dates, trajectoire, classification par l'objet, Namibie.

\section{Assessing land cover change in Namibia's Kavango East region: a multi-date object approach}

Land cover change is a global issue but its effects can be particularly severe in developing countries such as Namibia, by affecting the ecological functions of ecosystems and hence sustainable development. Namibia's arid conditions, due to low rainfall and high evapotranspiration rates, coupled with annual savannah fires, have resulted in a heterogenous landscape composed of a mixture of trees, shrubs and herbaceous plants. As a result, land cover maps are often inaccurate at the pixel level. Despite their relatively high accuracy, object-based image analyses are yet to be exhaustively applied to the dry tropical forests of Southern Africa. The purpose of this study was to apply a multi-date objectbased approach to land cover change, in order to determine its extent and dynamics in the heterogenous landscape of Kavango East, one of the regions with the highest forest cover in Namibia. Multidate segmentation, mean band values and image differentiation were used to detect land cover changes in four periods (1990, 2000, 2009 and 2016). The most common land conversion for all the periods was from forest to cropland. In 1990 , forests covered $58 \%$ of the land but by 2016 , this had dropped to $55 \%$. Meanwhile, cropland covered $3 \%$ of the study area in 1990 and had doubled to $6 \%$ by 2016 . The novel approach used in this study has produced promising results compared to traditional methods, which are prone to errors in detecting post-classification changes. The method can therefore be recommended for long term monitoring of land cover and land use change in areas with similar environmental and biophysical conditions.

Keywords: period, land cover change, land cover classification, Landsat, multidate segmentation, trajectory, objectbased classification, Namibia.

\section{Evaluación del cambio en la cubierta terrestre en la región este de Kavango, en Namibia: un enfoque basado en objetos multitemporal}

El cambio en la cubierta terrestre es un problema global pero sus efectos pueden ser particularmente severos en países en desarrollo como Namibia, afectando a las funciones ecológicas de los ecosistemas y, por tanto, a la sostenibilidad de su desarrollo. Las condiciones áridas de Namibia, debido a la baja pluviosidad y a las elevadas tasas de evapotranspiración, combinadas con los fuegos anuales de la sabana, han dado como resultado un paisaje heterogéneo compuesto por una mezcla de árboles, arbustos y plantas herbáceas. Por este motivo, los mapas de cubierta terrestre son a menudo poco precisos a nivel de píxeles. A pesar de su relativamente elevada precisión, los análisis de imágenes basados en objetos todavía tienen que aplicarse exhaustivamente a los bosques tropicales secos del África meridional. El objetivo de este estudio es aplicar un enfoque basado en objetos multitemporal para el cambio de cobertura del terreno: para determinar su alcance y dinámica en el paisaje heterogéneo de Kavango del Este, una de las regiones con la cobertura forestal más elevada de Namibia. La segmentación multitemporal, los valores de banda media y la diferenciación de imágenes se utilizaron para detectar cambios en la cubierta terrestre en cuatro períodos (1990, 2000, 2009 y 2016). La conversión más común para todos los períodos fue de bosque a tierras de cultivo. En 1990, los bosques ocupaban el $58 \%$ de las tierras, pero hacia 2016, habían descendido al $55 \%$. Por otra parte, las tierras de cultivo cubrían el $3 \%$ de la zona de estudio en 1990 y se habían duplicado al $6 \%$ hacia 2016. El nuevo enfoque utilizado en este estudio ha obtenido resultados prometedores en comparación con los métodos tradicionales, con tendencia a errores en la detección de cambios postclasificación. El método puede, por tanto, recomendarse para monitorizar a largo plazo la cubierta terrestre y el cambio en la utilización de las tierras en áreas con condiciones medioambientales y biofísicas similares.

Palabras clave: período, cambio de cubierta terrestre, clasificación de cubierta terrestre, Landsat, segmentación multitemporal, trayectoria, clasificación basada en objetos, Namibia. 


\section{Introduction}

The application of remote sensing to assess land cover changes has become more valuable than ever before, especially with a global trend of decreasing biodiversity and increasing species extinction (Dirzo et al., 2014). The expansion of agricultural fields and livestock production are the main drivers projected to influence biodiversity loss in Southern Africa over the next 100 years (Pröpper et al., 2010). Land cover change is a global problem but its effects can be particularly severe in developing countries such as Namibia because it not only affects biodiversity but also the social, cultural, and economic functions of ecosystems and can negatively affect sustainable development (Kamwi et al., 2015). It is therefore important to understand the dynamics of land cover change in the Namibian context, where it constitutes the basis of natural resources on which Namibians, in rural areas in particular, rely on as a source of their livelihoods. Two-thirds of the Namibian population depend on agricultural activities (FAO, 2001; Pröpper et al., 2010). Woodland savanna decreased over the last decades in northern and northeastern Namibia, mainly because of a doubling of the agricultural area (Wingate et al., 2016) for subsistence and cash crops.

Despite the Kavango East region being part of the Kavango Zambezi Trans Frontier Conservation Area (KAZATFCA) which is the largest transboundary conservation area in the world (Schultz et al., 2018), studies on land cover change in the conservation area are limited (Kamwi et al., 2018). The Kavango East is ecologically one of the most important regions in Namibia as it is part of the broadleafed savanna biome, with high tree species diversity and a large population of mammals (NBSAP, 2014). Pixel-based methods have been applied to detect land cover change in North-eastern Namibia (Wingate et al., 2016; Kamwi et al., 2018; Schultz et al., 2018). However, pixel-based image analysis has limitations because it is solely based on spectral characteristics of pixels and does not take into account the spatial arrangements of land cover features. Furthermore, pixel-based land cover change analysis is prone to post-classification change detection errors (Ernst et al., 2010). Namibia's arid conditions due to low rainfall and high evapotranspiration rates coupled with annual savanna fires, have resulted in a heterogenous landscape composed of a mixture of trees, shrubs and herbaceous plants. As such, mapping these ecosystems at pixel level often produce low accurate satellite-based land cover maps due to the inability to discriminate mixed land cover classes (Wingate et al., 2016).

Object-based image analysis uses spectral and spatial information to assign pixels into objects based on characteristics such as tone, size, shape, texture, patterns and the association between objects to assign a class. Object-based image analysis has been reported to be more accurate compared to pixel-based approaches (Esetlili et al., 2018; Jawak et al., 2018; Juniati and Arrofigoh, 2017). However, this depends on various factors such as the nature of the landscape, classification scheme, satellite sensor type and algorithms used to perform the actual analysis. The multi-date object-based land cover change approach has been applied on two time periods in the tropical dense forests (Desclée et al., 2006; Ernst et al., 2010). To the authors' knowledge, the multi-date object-based approach is yet to be applied on a series of four time periods in the dry tropical forests of Southern Africa.

It is within this framework that an object-based approach for land cover change mapping in the open savanna woodlands of North-eastern Namibia was applied. Multi-date segmentation, mean band values and image differencing were applied to assess land cover change from four periods (1990, 2000, 2009 and 2016) in Kavango East region, Namibia. The overall objective of the study was to determine the extent and dynamics of land cover change in the heterogenous landscape of Kavango East region over the 26-year period based on an object approach.

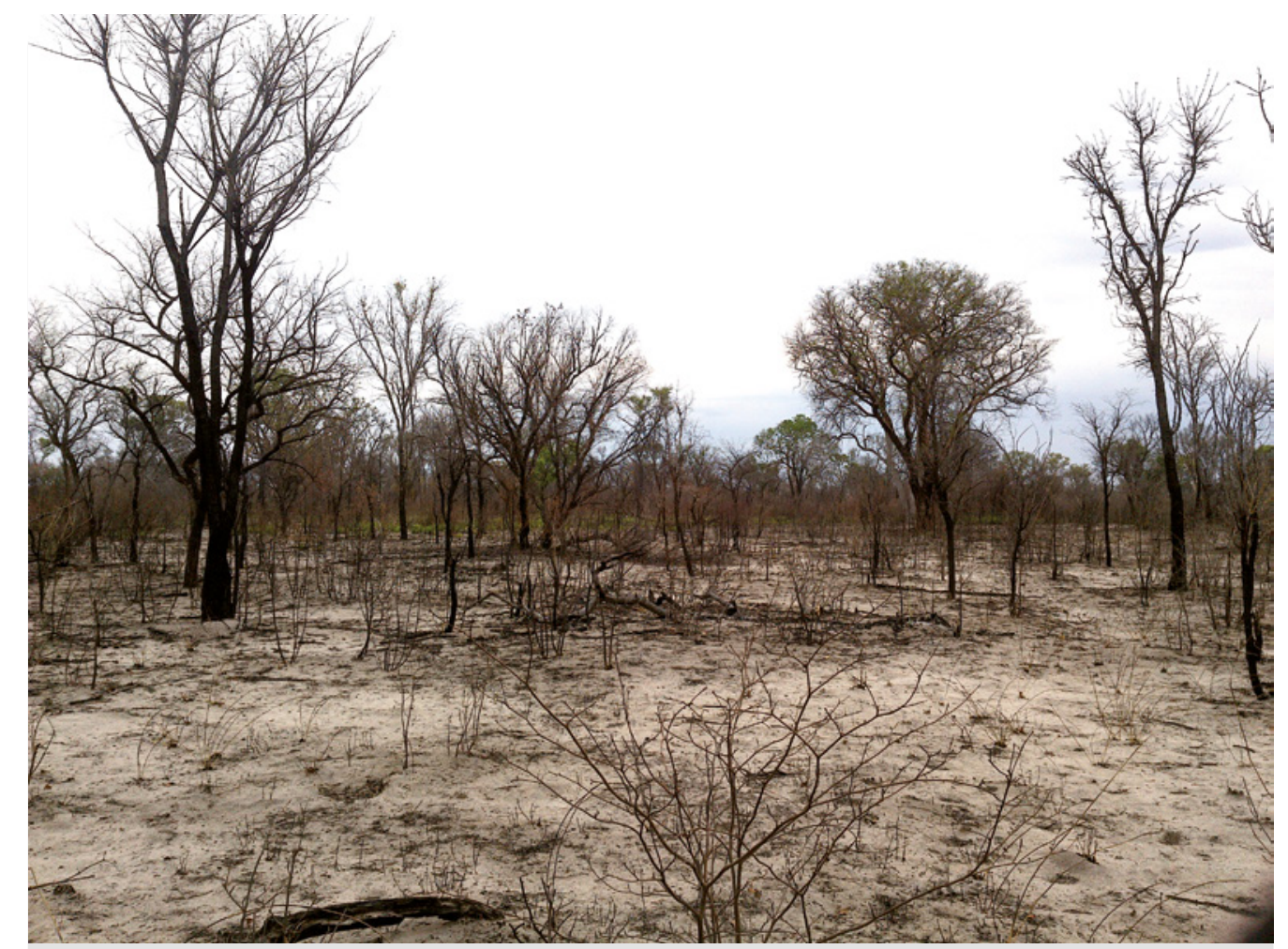

Photo 2.

Forest fires are common in the study area. Photo E. Muhoko. 


\section{Methods}

\section{Study area}

The study area is the Kavango East Region and is located in the North-eastern parts of Namibia (figure 1). It covers an area of 2,388,200 ha of which most parts have been declared as communal land. The region is bordered by Angola in the north and Botswana in the south east. Kalahari sands are predominant in the study area, specifically low fertile Ferralic Arenosols are the dominant soil type. The landscape is uniform with a predominantly plain topography at an average elevation of $900 \mathrm{~m}$ above sea level. Old longitudinal sand dunes are found on the North eastern parts of the study area. The mean maximum temperature is higher than $30^{\circ} \mathrm{C}$ for most of the year while average minimums of less than $10^{\circ} \mathrm{C}$ are recorded in the winter months of June, July and August (MLR, 2015). The annual rainfall ranges from $500 \mathrm{~mm}$ to $750 \mathrm{~mm}$ (Mendelsohn et al., 2002).

Kavango East contains two national parks namely the Kaudum and Bwabwata national parks and eight gazetted community forests (figure 1). Community forests are managed by local community members for the purpose of sustainable management of forests and forest products (Directorate of Forestry, 2012). The dominant tree species in the study area are Burkea africana, Baikiaea plurijuga and Pterocarpus angolensis. Pterocarpus angolensis is regarded as the most economically valuable tree species because of its timber (De Cauwer, 2015). Due to its high economic value, $P$. angolensis has become one of the targeted timber species as a source of extra cash for the local land users (Pröpper and Vollan, 2013). Most people live along the Okavango river as the river provides food resources and water. Seasonal fires happen every year from June up to November, just before the beginning of the rainy season. Due to its high biomass content, burned areas are among the highest in the country. The highest burned area figures are usually recorded during the months of August/September (Stellmes et al., 2013).

\section{Image acquisition and pre-processing}

The methodology is divided into two main steps namely image acquisition and pre-processing (1), and image processing (2) (figure 2). The Landsat series was downloaded from the United States Geological Survey ${ }^{1}$ for the May-June period (table I). This period is the beginning of the dry season and vegetation greenness is still in peak condition. Satellite imagery are affected by atmospheric conditions such as haze, sun-illumination angle and atmospheric scattering. Therefore, preprocessing of satellite imagery is a fundamental step in digital image analysis as this improves the quality of the image before further analysis is performed (Campbell and Wynne, 2011). All the datasets were level 1 products, therefore geometric correction was not necessary as it was already performed by the data provider. The "Radiometric Calibration" tool in the ENVI software was used to convert Digital Numbers (DN) to Top of the Atmosphere (TOA) reflectance (Flood, 2014). To complete the atmospheric correction process, the TOA was converted to Surface Reflectance (SR) by applying the Dark Object Subtraction (DOS) technique using the "Dark Subtraction" tool. The DOS modifies the additive effects of scattering due to the atmosphere. The atmosphere can cause dark pixels to appear bright and bright pixels to appear dark (Campbell and Wynne, 2011). Therefore, the DOS method adjusts pixels to their "true surface" reflectance values. A seamless mosaic was then applied on the image files to produce a single image file for each year of the study.

\section{${ }^{1}$ https://earthexplorer.usgs.gov}

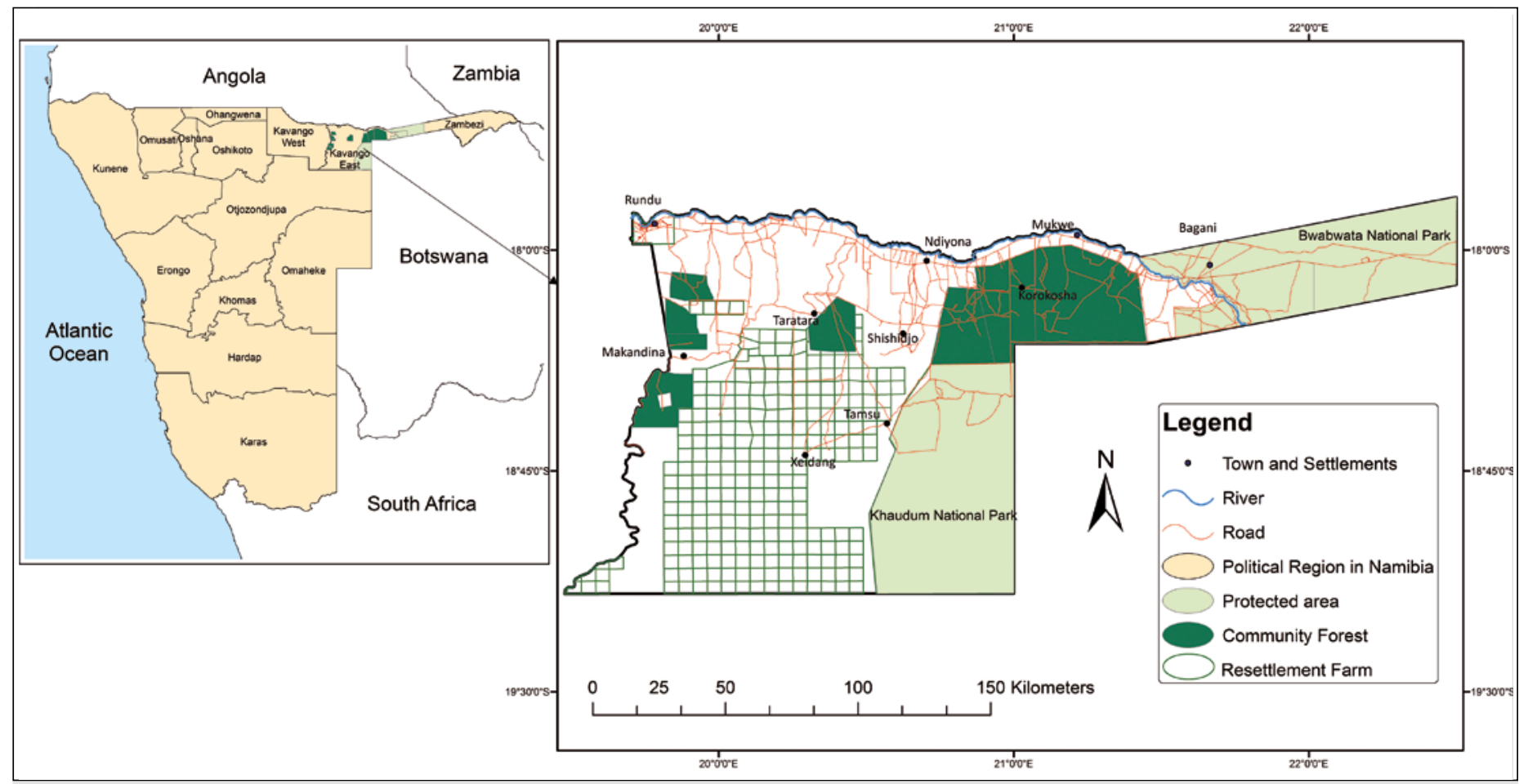

Figure 1.

Location of the study area: the Kavango East region in north-eastern Namibia. 


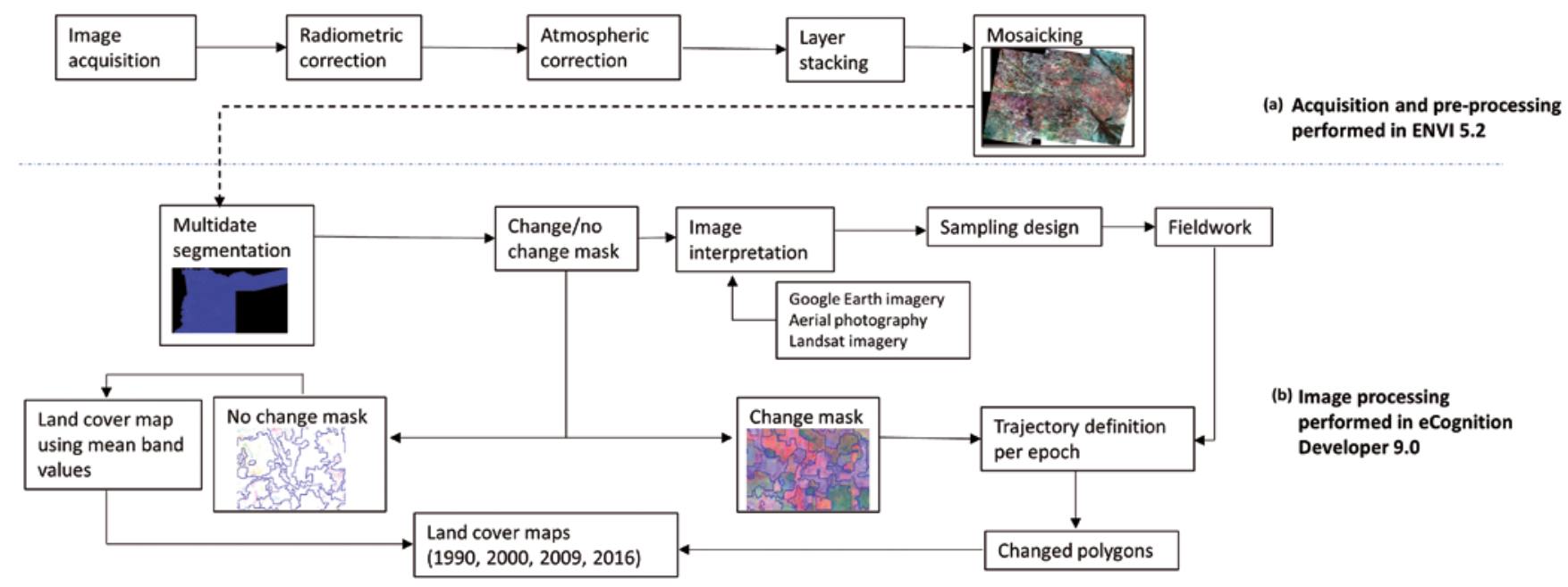

Figure 2.

Flow chart of image processing. The dashed lines indicate the completion of the main steps.

\section{Image processing}

Table I.

Satellite data specifications.

\begin{tabular}{|c|c|c|c|c|c|c|c|}
\hline Year & Satellite & Sensor & Pixel Size (m) & Bit/pixel & Path & Row & Acquisition Date \\
\hline \multirow[t]{6}{*}{1990} & \multirow[t]{6}{*}{ Landsat 5} & \multirow[t]{6}{*}{ TM } & \multirow[t]{6}{*}{30} & \multirow[t]{6}{*}{8} & 175 & 72 & $26-06-90$ \\
\hline & & & & & 175 & 73 & $26-06-90$ \\
\hline & & & & & 176 & 72 & $17-06-90$ \\
\hline & & & & & 176 & 73 & $17-06-90$ \\
\hline & & & & & 177 & 72 & $24-06-90$ \\
\hline & & & & & 177 & 73 & $24-06-90$ \\
\hline \multirow[t]{6}{*}{2000} & \multirow[t]{6}{*}{ Landsat 5} & \multirow[t]{6}{*}{ TM } & \multirow[t]{6}{*}{30} & \multirow[t]{6}{*}{8} & 175 & 72 & 07-06-00 \\
\hline & & & & & 175 & 73 & $07-06-00$ \\
\hline & & & & & 176 & 72 & $28-06-00$ \\
\hline & & & & & 176 & 73 & $28-06-00$ \\
\hline & & & & & 177 & 72 & $25-05-00$ \\
\hline & & & & & 177 & 73 & $25-05-00$ \\
\hline \multirow[t]{6}{*}{2009} & \multirow[t]{6}{*}{ Landsat 5} & \multirow[t]{6}{*}{ TM } & \multirow[t]{6}{*}{30} & \multirow[t]{6}{*}{8} & 175 & 72 & $16-05-09$ \\
\hline & & & & & 175 & 73 & $16-05-09$ \\
\hline & & & & & 176 & 72 & 04-05-09 \\
\hline & & & & & 176 & 73 & 04-05-09 \\
\hline & & & & & 177 & 72 & 27-05-09 \\
\hline & & & & & 177 & 73 & 27-05-09 \\
\hline \multirow[t]{6}{*}{2016} & \multirow[t]{6}{*}{ Landsat 8} & \multirow[t]{6}{*}{ OLI } & \multirow[t]{6}{*}{30} & \multirow[t]{6}{*}{16} & 175 & 72 & 01-06-16 \\
\hline & & & & & 175 & 73 & 01-06-16 \\
\hline & & & & & 176 & 72 & $08-06-16$ \\
\hline & & & & & 176 & 73 & $08-06-16$ \\
\hline & & & & & 177 & 72 & $15-06-16$ \\
\hline & & & & & 177 & 73 & $15-06-16$ \\
\hline
\end{tabular}

\section{Multi-date segmentation}

Image segmentation is the process of dividing an image at pixel level into small clusters called objects, the objects then become the building blocks for further image analysis (Desclée et al., 2006; Trimble, 2014). The multi-date image segmentation approach delineates objects from a minimum of two periods into spectrally and spatially homogenous land cover change trajectories (Desclée et al., 2006; Ernst et al., 2010). The multi-temporal segmentation was applied on four dates (1990, 2000, 2009 and 2016). The purpose of this approach was to detect and identify changed and unchanged objects from the four time periods (figure 3). Four bands from the Operational Land Imager (OLI) and Thematic Mapper (TM) were used and had equal layer weights: Red, Near Infrared (NIR), Shortwave Infrared 1 (SWIR1) and Shortwave Infrared 2 (SWIR2). The Coastal Aerosol, Blue and Green bands were not used due to their susceptibility to atmospheric scattering (Verhegghen et al., 2010).

The multi-resolution segmentation algorithm was used to partition the objects. Parameters were adjusted so both the shape and compactness values were set to 0 , and the scale parameter set 
to 1 to obtain a satisfactory segmentation based on empirical assessments. These settings produced the best object segmentation results. Therefore, the scale parameter of 1 ha was the Minimum Mapping Unit (MMU) for this study.

The change and no change masks were created by performing an initial classification using the "max diff" and "mean brightness" tools (Trimble, 2014) (figure 3). The "max diff" tool measures the mean intensity of an object from a minimum of two image layers in relation to the brightness of such an object, according to equation (1) adopted from Trimble (2014),

$\operatorname{Max} \operatorname{Diff}=\frac{\max _{i, j \varepsilon K_{B}}\left|\bar{c}_{i}(v)-\bar{c}_{j}(v)\right|}{\bar{c}(v)} \quad$ (equation 1)

where

$\bullet i, j$ are image layers,

- $\bar{c}(v)$ is the brightness of image object $v$,

- $\bar{c}_{i}(v)$ is the mean intensity of image layer $i$ of image object $v$, - $\bar{c}_{j}(v)$ is the mean intensity of image layer $j$ of image object $v$, - $\max _{i, j}$ are the brightest possible intensity values of image layer $\kappa_{B}$,

- $K_{B}$ are image layers of positive brightness weight with $\kappa_{B}=\left\{k \in K: w_{k}=1\right\}$.

The mean brightness tool measures the mean intensity of an object based on an image layer given by equation (2) (Trimble, 2014),

$\bar{c}(v)=\frac{1}{W^{B}} \sum_{k=1}^{K} W_{k}^{B} \bar{c}_{k}(v) \quad$ (equation 2)

where

- $W_{k}^{B}$ is the brightness weight of image layer $k$ with $W_{k}^{B}\left\{_{1}\right.$,

- $K$ is the number of image layers used for calculation,

- $w^{B}$ is the sum of brightness weights of all image layers used for calculation with $w^{B}=\sum_{k=1}^{K} W_{k}^{B}$,

- $\bar{c}_{k}(v)$ is the mean intensity of image layer of image object.

The creation of the masks ensured that the land cover change trajectories would only be interpreted and mapped within the change masks, while the unchanged land cover would only be mapped within the no change mask. Changed objects have abnormal spectral signature characteristics and are therefore, brighter compared to unchanged objects (Desclée et al., 2006; Ernst et al., 2010; Verhegghen et al., 2010). To perform an initial classification to create the change/no change masks, the "max diff" and "brightness" were determined by an empirical approach. This was performed by testing various threshold values and it was discovered that both "max diff" and "brightness" values less than 1 appeared to satisfactorily classify the no change mask. Furthermore, "max diff" and "brightness" values greater than 1 appeared to satisfactorily classify the change mask.

The spectral signatures of the land cover features were analysed over the 26-year period on the TM and OLI imagery. Furthermore, orthophotos and Google Earth imagery were used to supplement the photo interpretation of the Landsat imagery. Orthophotos for the year 1996, 2007 and 2012 were used. The 1996 photographs were obtained from Raison Namibia while the 2007 and 2012 photographs were obtained from Namibia Statistics Agency (NSA). The 2007 and 2012 photos were in colour and were used to observe the temporal characteristics of the land cover features and validate the changed and no change masks.

A total of 210 sample points were created using the stratified random sampling method (figure 4) based on the change and no change mask, this ensured that both strata were sampled. Field work which was carried out in November 2017, included recording the existing land cover classes and capturing geotagged photographs of the site in the northern, eastern, western and southern directions on the field data sheet. Furthermore, observed human and natural events such as logging, soil erosion, among others, were recorded. The goal of the field work was to gain an understanding about the history of the land cover change trajectories. To achieve this, local residents were interviewed about their possible knowledge on the land cover change trajectories in the past, including land use activities. The local residents interviewed

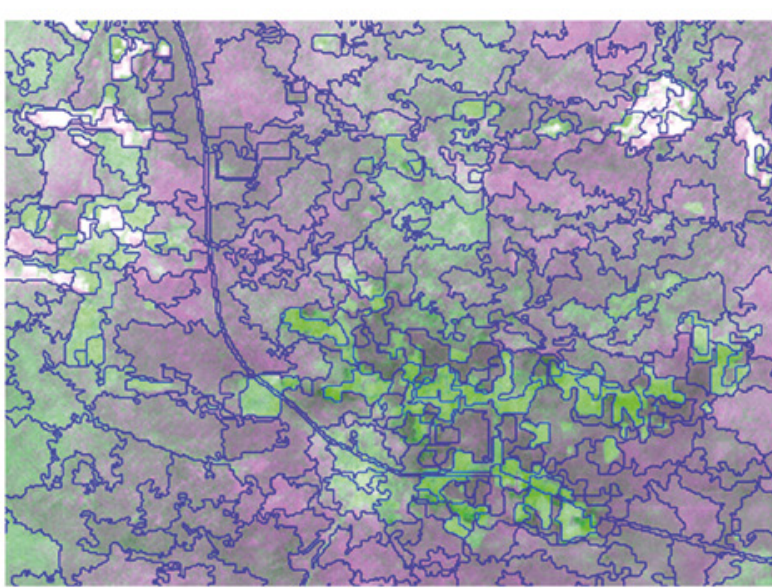

a) Multidate segmentation

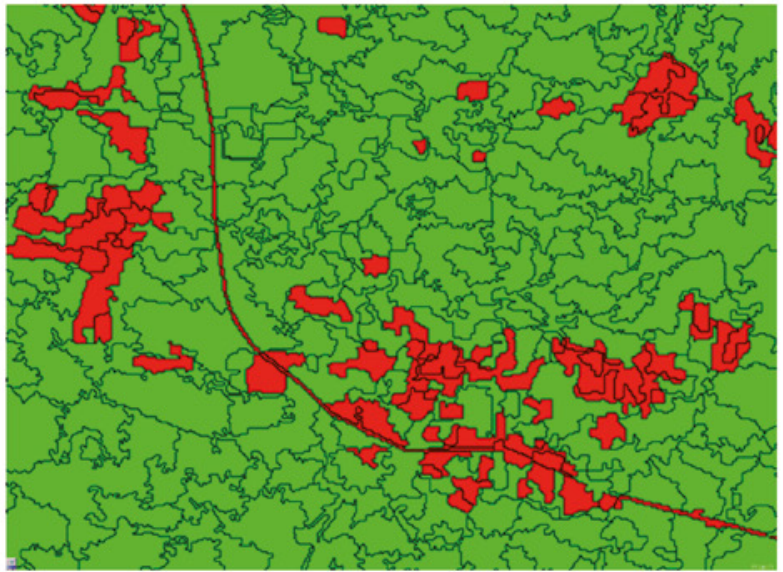

b) Change mask (Red) and No change mask (Green)

Figure 3.

The Multi-date segmentation (a) and the change and no change masks (b) produced from the segmentation and the image differencing thresholds. 
were village headmen (4), a traditional chief (1), commercial and subsistence farmers (18), forest rangers (2), game ranger (1), local authority officials (2) and teachers (6). The information provided by the local residents was only used to interpret imagery in the change and no change masks. Furthermore, 486point data collected on forest and non-forest either by forest inventory, field observations by De Cauwer et al. (2016), the Directorate of Forestry (2013) and Google Earth imagery were used in addition to the 210 samples collected from fieldwork.

\section{Object-based classification}

The classification legend used was based on the International Panel on Climate Change (IPCC) classification scheme (IPCC, 2003). The bushland and bare land were added by the authors based on field observations. Therefore, a total of 7 classes as described in table II.

Object-based classification was analysed using Trimble's eCognition Developer version 9.0. The eCognition software uses rule sets to perform a segmentation, classification and exports the output either as raster or vector. Rule sets are decision rules which use thresholds determined by the user to perform a function. Under the no change mask, cropland areas were extracted using the "mean brightness", "rectangular fit" and "elliptic fit feature" tools. The "rectangular fit" tool can be used to label how well objects will fit into a rectangle of the same proportion and size, values range from 0 to 1 , with 1 indicating a perfect rectangular object shape (Trimble, 2014). Furthermore, the elliptic fit can be used to label how well objects will fit into an ellipse or circle of the same size and proportion. A value of 1 indicates that the object has a perfect elliptic or circular shape while 0 indicates that the object is not round at all (Trimble, 2014). Cropland had mean brightness values greater than 0.2. Crop fields were rectangular in shape in the communal areas while there were circular on commercial farms. The mean brightness threshold value together with the rectangular fit value of more

than 0.5 and the elliptic

Table II.

Classification scheme description.

\begin{tabular}{ll}
$\begin{array}{ll}\text { Class } \\
\text { Forest land }\end{array}$ & $\begin{array}{l}\text { Description } \\
\text { Areas of more than } 0.5 \text { ha consisting of trees with a minimum height of } 3 \mathrm{~m} \\
\text { and a canopy cover of more than } 10 \%\end{array}$ \\
\hline Bushland & $\begin{array}{l}\text { Areas of more than } 0.5 \text { ha predominantly consisting of bushes, shrubs } \\
\text { and trees with a height less than } 3 \mathrm{~m} \text { and a canopy cover of more than } 10 \%\end{array}$ \\
\hline Grassland & $\begin{array}{l}\text { Areas dominated by grass (canopy cover more than } 50 \% \text { ) including rangelands } \\
\text { and pasture with a few shrubs, trees and bushes (canopy cover less than 10\%) }\end{array}$ \\
\hline Settlement & $\begin{array}{l}\text { Areas consisting of built up areas, road infrastructure and human settlements } \\
\text { with a population of more than } 1000\end{array}$ \\
\hline Cropland & Areas used to produce food for both subsistence and commercial purposes \\
\hline Wetland & Areas predominantly wet for most of the year consisting of rivers and lakes \\
\hline Bare land & $\begin{array}{l}\text { Area not classified as forest, bushland, grassland, settlement, cropland } \\
\text { and wet land and are bare in nature. This includes rocky areas and pans. }\end{array}$ \\
\hline
\end{tabular}

fit value of more than 0.5 were used to classify cropland. These values seemed to produce a satisfactory discrimination between cropland and non-cropland features.

The Normalized Difference Vegetation Index (NDVI) was used to classify forest and non-forest areas. The NDVI uses a ratio of the reflectance values between the Near infrared band and Red band and is one of the most used indices in remote sensing (Cracknell, 2001). The NDVI is highly correlated with photosynthetic activities and chlorophyll content in vegetation (Myneni et al., 1995; Tucker et al., 2005). Forest areas tend to have high NDVI values compared to non-forest areas. Under the no change mask, mean band values were used to classify the land cover types. For instance, because objects under this mask have remained unchanged, the NDVI for all the years (1990, 2000, 2009 and 2016) were averaged and used to classify forest land, bushland and grassland. Data from field observations and image interpretation were used to determine a threshold value to

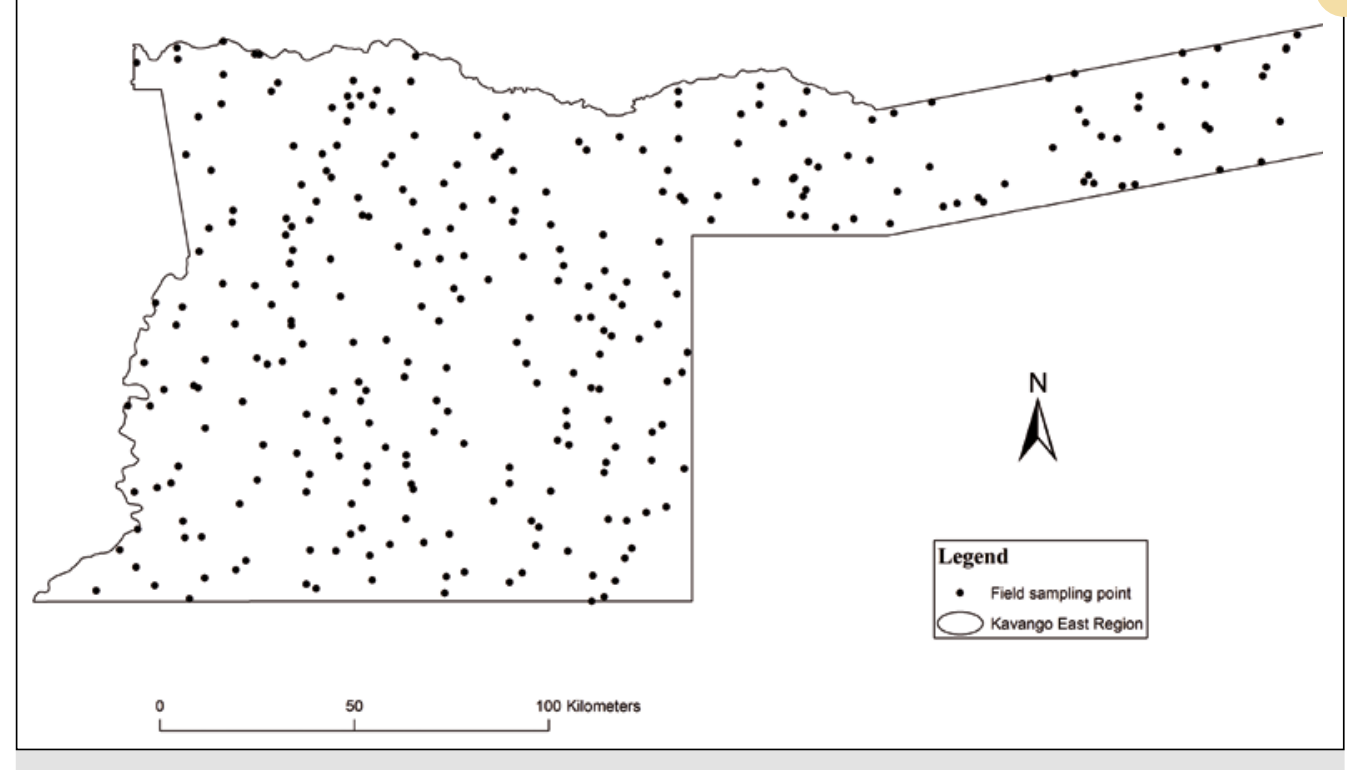

Figure 4.
An illustration of the spatial distribution of the field data. 


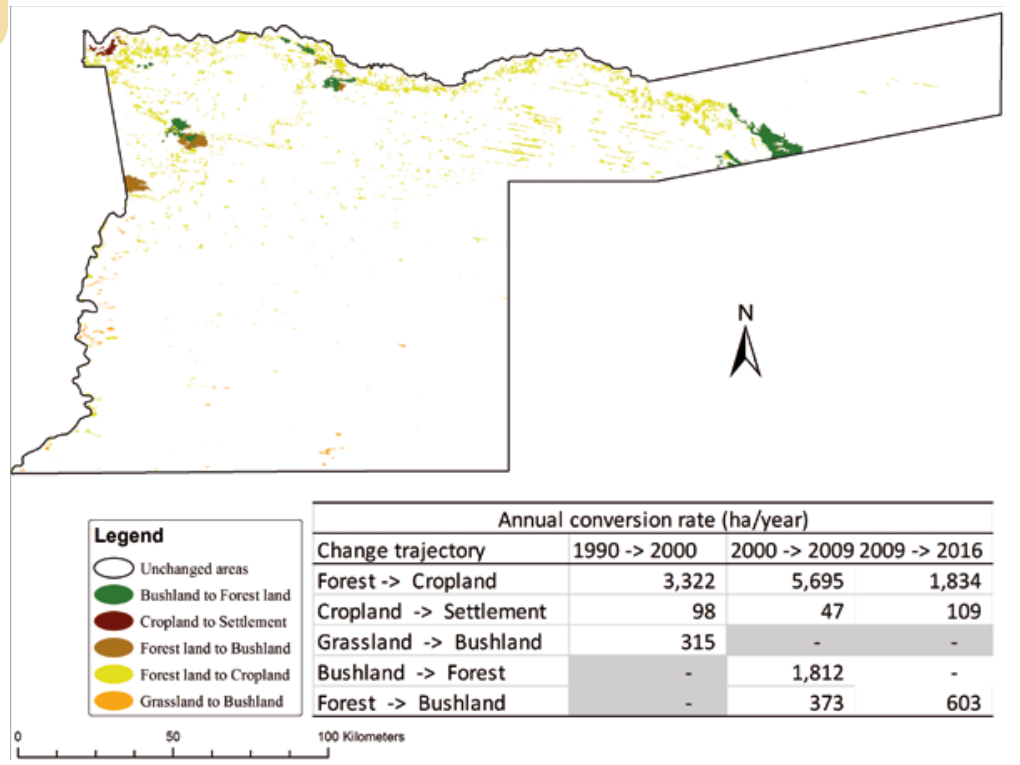

Figure 5.

Changed areas from 1990 to 2016. Grey areas indicate that no trajectory was observed within an epoch. "copy map" tool was used to copy the 1990 image layers, 2000 image layers and the objects produced from the multi-date segmentation stage into the new 1990-2000 map. Mean band values from the difference of the NIR between the two years (NIR2000NIR1990) were used to detect land cover trajectories (Desclée et al., 2006). When the difference of the NIR was greater than 0.01 changes were correctly detected. Information gathered from the image interpretation stage, field work as well insights from the locals were used to define the detected trajectory. For instance, if from image interpretation it was identified that forest land in 1990 became crop land in 2000, the trajectory was confirmed with farmers or residents who have lived at the site since 1990. Under the 1990 land cover map, the trajectory "forest land in 1990 to cropland in 2000" was labeled as forest land, while on the 2000 land cover map it was labeled as cropland. These procedures were repeated for the 2000-2009 and 2009-2016 epochs. The changed polygons from the change masks and the land cover map from the unchanged mask were combined to produce 1990, 2000, 2009 and 2016 land cover maps.

The accuracy of the land cover maps was discriminate forestland from bushland and grassland. A NDVI of 0.31 was the minimum value for forest land. Using this as a threshold, all vegetation which had a minimum NDVI value of 0.31 was classified as forest land. The NDVI values for bushland ranged from 0.25 to 0.30 . All NDVI values of less than 0.25 were classified as grassland or settlement.

The settlement class was extracted using a combination of the NDVI and the Normalized Difference Built-up Index (NDBI) values. The NDBI is a ratio between the short-wave infrared band and the near infrared band. Built up areas and bare land have higher reflectance values in the short-wave infrared than in the near infrared (Zha et al., 2003). To discriminate the settlement areas and bare land from grassland, NDBI values were subtracted from the NDVI (NDVI-NDBI). The positive values are built-up areas and bare land while negative values are water and vegetation (Zha et al., 2003). Based on this, positive values were classified as settlements and bare land while negative values were classified as grassland. To further discriminate settlements from bare land, mean brightness values greater than 0.5 were used to classify settlements. Settlements appeared brighter compared to bare land. Water completely absorbs the NIR band and therefore appears dark in colour. As such, mean NIR band values were used to determine the appropriate threshold to classify wetland. Mean NIR values less than 0.18 appeared to successfully discriminate water bodies from other land cover classes. Therefore, all objects with mean NIR less than 0.18 were labeled as wetland. The resultant product from this ruleset classification was the unchanged land cover map.

Land cover change trajectories were analysed on the change mask. To track the land cover trajectory per epoch, the "copy map" and "synchronize map" tools of eCognition were used. Change trajectories were identified and defined per epoch (1990-2000, 2000-2009 and 2009-2016). The assessed using independent validation points produced from Google Earth imagery. For each land cover map, validation points were randomly created in ESRI's ArcGIS 10.1 software and overlaid in Google Earth. The land cover was recorded by zooming on the random point and then labeling the existing land cover on such a point. The "time slider" tool was used to observe the historical images for 2009, 2000 and 1990 . As a result, a total of 591 random points were acquired for 2016, 265 for 2009, 253 for 2000 and 150 for 1990. The "Confusion Matrix Using Ground Truth ROI" tool in ENVI 5.2 was used to measure the accuracy of the land cover maps. The validation points were converted to Region of Interest (ROI) points to produce a confusion matrix. The overall accuracy, Kappa coefficient, user accuracy and producer accuracy values were obtained from the confusion matrix.

\section{Results}

\section{Detected change trajectories}

Changed areas related to land use such as agricultural expansion from 1990 to 2016 in Kavango East are shown in figure 5 . Other changes such as vegetation loss due to wild fires were also observed but they were regarded to be beyond the scope of this study (photo 2). To gain an understanding on the detected changes, 1990 to 2016 burned area polygons obtained from the Directorate of Forestry (DoF) in Namibia and fire return periods products revealed that forest fires are frequent in these areas. Visual observations on Google Earth further showed that forest fires mainly burn bushes and grasses, but the vegetation quickly regenerates after the next rainy season.

The conversion forest land to cropland occurred in all the epochs (photo 3). From 1990 to 2000 to 33,223 ha of 
forest land were converted to cropland (figure 5). This then corresponded to annual conversion of 3,322 ha. There was a sharp increase in forest areas converted to cropland in the 2000-2009 epoch with a total of 51,253 ha and an annual conversion of 5,695 ha. In the 2009-2016 epoch, forest loss due to cropland decreased to 12,838 ha with an annual conversion of 1,834 ha.

The trajectory from cropland to settlement was observed in all the epochs, especially in the northwestern parts of the study area. About 98 ha of cropland were converted to settlement per year in the 1990-2000 epoch. In 2000-2009, it was reduced to 47 ha per year before increasing to 107 ha per year between 20092016. Urbanization rates are relatively low in Kavango East as most people still live in rural areas (NSA, 2012). Even if people are to migrate in search of better socio-economic opportunities, the capital Windhoek remains their preferred destination (NSA, 2012). Forest regrowth was detected in the 2009-2016 epoch. A total of 16,309 ha of bushland became forest land in 2016 . This may be related to the above normal rainfall Namibia received between 2006 to 2011 (Namibia Meteorological Service, 2014) and the fact that the difference between bushland and open forest is very small.

\section{Land cover in Kavango East}

The land cover maps show that the cropland class exhibited a linear pattern along the Okavango river and other dry fossil rivers (figure 6). Furthermore, there has been an expansion in cropland areas in the northwestern and north eastern parts of the study area. The distribution of the forest class was relatively uniform in the study area, with most disturbances occurring along the rivers (dry and permanent) and roads. The central, southwestern, and eastern parts have largely remained unchanged. The bushland class was mainly distributed on the southwestern and southeastern parts of the study area while a few patches can be observed on the northeastern parts.

The grassland class was found mostly in the northern parts in the flood plains along the river, with a few patches in the south. Bare land was mainly distributed in the northeastern parts where salt

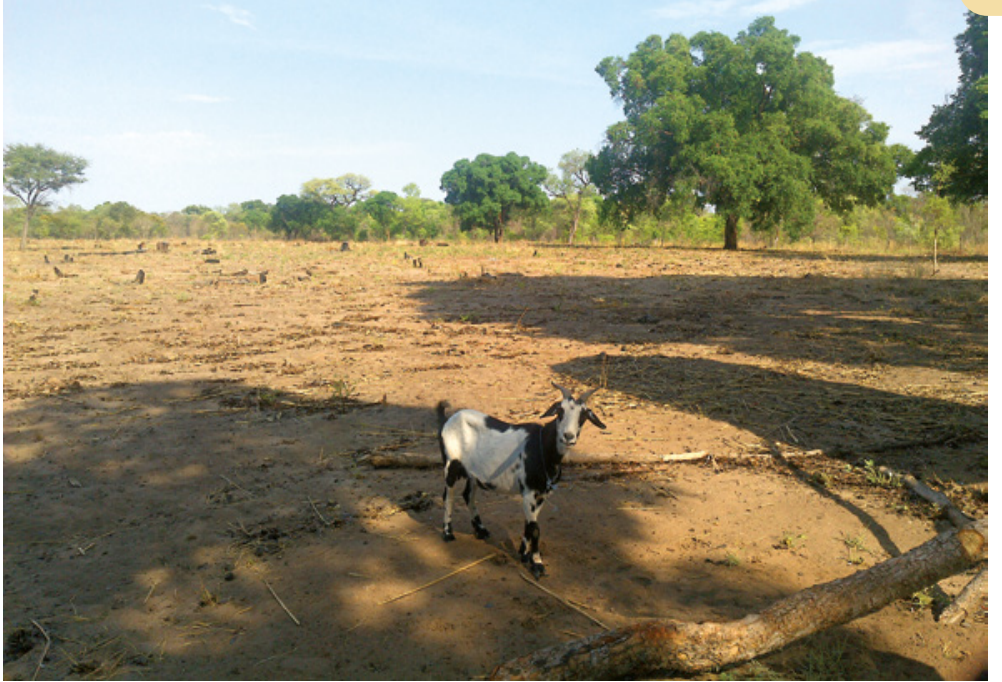

Photo 3.

A crop field after a harvesting season in Kavango East. The conversion from forest land to cropland is a common practice in the study area. Photo E. Muhoko.

pans are found. Forest land was the dominant land cover in all years followed by bushland in second and cropland third (table III). In fact, more than half of the study area was covered by forest land (58\% in 1990, 56\% in 2000, 55\% in 2009 and $54 \%$ in 2016). This indicates that there was a gradual decrease in forest land from 1990 to 2016 . The highest land cover for the bushland class was in 2016 with $39 \%$. Furthermore, cropland doubled from 3\% in 1990 to $6 \%$ in 2016 . This indicates that agriculture still remained the main source of the livelihood for the expanding population of Kavango East. The settlement class covered 0.07\% of the study area in 1990 and reached $0.14 \%$ in 2016. 
Bois et Forêts des Tropiques - ISSN: L-0006-579X

Volume $344-2^{\text {nd }}$ quarter - July 2020 - p. 17-32

OCUS ON... / LAND COVER CHANGE

Table III.

Land cover composition for 1990, 2000, 2009 and 2016.

\begin{tabular}{|c|c|c|c|c|c|c|c|c|}
\hline \multirow[t]{2}{*}{ Land Cover type } & \multicolumn{2}{|c|}{1990} & \multicolumn{2}{|c|}{2000} & \multicolumn{2}{|c|}{2009} & \multicolumn{2}{|c|}{2016} \\
\hline & Area (ha) & Area (\%) & Area (ha) & Area (\%) & Area (ha) & Area (\%) & Area (ha) & Area (\%) \\
\hline Forest land & $1,376,140$ & 58 & $1,326,960.0$ & 56 & $1,310,680$ & 55 & $1,293,680$ & 54 \\
\hline Bushland & 906,245 & 38 & $925,139.0$ & 39 & 917,318 & 38 & 928,193 & 39 \\
\hline Cropland & 69,838 & 3 & $102,208.0$ & 4 & 129,881 & 5 & 145,405 & 6 \\
\hline Grassland & 21,225 & 0.9 & $183,37.1$ & 0.8 & 14,523 & 0.6 & 8,583 & 0.4 \\
\hline Settlement & 1,725 & 0.1 & $2,616.2$ & 0.1 & 2,850 & 0.1 & 3,376 & 0.1 \\
\hline Bare land & 9,633 & 0.4 & $9,641.0$ & 0.4 & 9,592 & 0.4 & 5,638 & 0.2 \\
\hline Wetland & 3,475 & 0.1 & $3,338.2$ & 0.1 & 3,409 & 0.1 & 3,409 & 0.1 \\
\hline Total & $2,388,287$ & 100 & $2,388,287$ & 100 & $2,388,287$ & 100 & $2,388,287$ & 100 \\
\hline
\end{tabular}

Table IV.

Accuracy assessment results for the 2016 classification.

\begin{tabular}{|l|c|c|c|c|c|}
\hline Class & $\begin{array}{c}\text { Producer } \\
\text { accuracy (\%) }\end{array}$ & $\begin{array}{c}\text { User } \\
\text { accuracy (\%) }\end{array}$ & $\begin{array}{c}\text { Commission } \\
\text { error (\%) }\end{array}$ & $\begin{array}{c}\text { Omission } \\
\text { error (\%) }\end{array}$ & $\begin{array}{c}\text { Reference } \\
\text { points }\end{array}$ \\
\hline Bare land & 25 & 94 & 6 & 75 & 16 \\
\hline Bushland & 84 & 68 & 32 & 16 & 133 \\
\hline Forest land & 90 & 87 & 13 & 10 & 162 \\
\hline Cropland & 95 & 87 & 14 & 6 & 178 \\
\hline Grassland & 56 & 54 & 46 & 44 & 37 \\
\hline Settlement & 87 & 100 & 0 & 13 & 26 \\
\hline Wetland & 85 & 100 & 0 & 15 & 33 \\
\hline Total & & & & & 591 \\
\hline Overall accuracy (\%) & $\mathbf{8 1}$ & & & & \\
\hline Kappa coefficient & $\mathbf{0 . 7 6}$ & & & & \\
\hline
\end{tabular}

Table V.

Accuracy assessment results for the 2009 classification.

\begin{tabular}{|l|c|c|c|c|c|}
\hline Class & $\begin{array}{c}\text { Producer } \\
\text { accuracy (\%) }\end{array}$ & $\begin{array}{c}\text { User } \\
\text { accuracy (\%) }\end{array}$ & $\begin{array}{c}\text { Commission } \\
\text { error (\%) }\end{array}$ & $\begin{array}{c}\text { Omission } \\
\text { error (\%) }\end{array}$ & $\begin{array}{c}\text { Reference } \\
\text { points }\end{array}$ \\
\hline Settlement & 70 & 100 & 0 & 30 & 7 \\
\hline Grassland & 93 & 90 & 10 & 7 & 29 \\
\hline Bushland & 69 & 78 & 22 & 31 & 51 \\
\hline Wetland & 91 & 100 & 0 & 9 & 32 \\
\hline Forest land & 87 & 71 & 29 & 13 & 83 \\
\hline Cropland & 74 & 80 & 20 & 26 & 46 \\
\hline Bare land & 31 & 83 & 17 & 69 & 6 \\
\hline Total & & & & & 265 \\
\hline Overall Accuracy (\%) & $\mathbf{7 8}$ & & & & \\
\hline Kappa coefficient & $\mathbf{0 . 7 3}$ & & & & \\
\hline
\end{tabular}

\section{Accuracy of the classification}

Independent reference points generated from Google Earth using visual interpretation were used to assess the accuracy of the classification for all the maps. Table IV shows the accuracy assessment results for the 2016 classified image. The overall classification accuracy achieved for the 2016 classification was $81 \%$ with a Kappa coefficient of 0.76 . Studies in comparable ecosystems have achieved overall accuracy values in the range of $60 \%$ to $90 \%$ when image classification was performed using Landsat imagery (Mango et al., 2011; Kamwi et al., 2018).

A Kappa value between 0.700.80 is interpreted as substantial agreement (Viera and Garret, 2005). Therefore, the values obtained in this study denote an acceptable classification result. For the 2016 classification, cropland and forest land had the highest producer accuracy of $95 \%$ and $90 \%$, respectively. Wetland and settlement both had the highest user accuracy of $100 \%$. This then corresponded to the lowest commission errors of $0 \%$ for both. Bare land and grassland had the lowest producer accuracy with $25 \%$ and $56 \%$, respectively. The overall accuracy for the 2009 classification was $78 \%$ (table V), for the 2000 classification was $81 \%$ (table $\mathrm{VI}$ ) and 1990 classification it was 75\% (table VII).

A confusion matrix (table VIII) for the 2016 classification reveals 
that 16 pixels under bare land were incorrectly classified as grassland, while 21 pixels were incorrectly classified as bushland. Furthermore, 9 pixels under grassland were incorrectly classified as bushland and 1 pixel was incorrectly classified as bushland. The 2009 confusion matrix table shows that only 40 pixels out of 58 were correctly classified as bushland, with 17 pixels misclassified as forest land. Bare land had 5 out of 16 pixels correctly classified while 5 pixels were misclassified as bushland. Compared to other classes, bushland and bare land had the highest number of misclassified pixels (table IX).

The 2000 confusion matrix (table $X$ ) reveals a similar scenario with 8 out of 25 pixels were correctly classified as bare land, with 8 and 6 pixels misclassified as bushland and grassland, respectively. While the 1990 classification also shows that out of 20 pixels under bare land, 5 were misclassified as bushland, 4 misclassified as grassland (table XI).

\section{Discussion}

\section{Land cover mapping}

The land cover mapping process assessed the spatial distribution of the land cover types as well as the extent of land cover change as displayed by the thematic maps for 1990, 2000, 2009 and 2016. The use of mean NDVI values to map forest land and bushland resulted in high producer accuracy values for the 2016 map with $90 \%$ and $84 \%$, respectively. This corroborates

Table VI.

Accuracy assessment for the 2000 classification.

\begin{tabular}{|l|c|c|c|c|c|}
\hline Class & $\begin{array}{c}\text { Producer } \\
\text { accuracy (\%) }\end{array}$ & $\begin{array}{c}\text { User } \\
\text { accuracy (\%) }\end{array}$ & $\begin{array}{c}\text { Commission } \\
\text { error (\%) }\end{array}$ & $\begin{array}{c}\text { Omission } \\
\text { error (\%) }\end{array}$ & $\begin{array}{c}\text { Reference } \\
\text { points }\end{array}$ \\
\hline Wetland & 82 & 100 & 0 & 18 & 9 \\
\hline Settlement & 87 & 93 & 7 & 13 & 14 \\
\hline Grassland & 65 & 65 & 35 & 35 & 20 \\
\hline Forest land & 89 & 88 & 12 & 11 & 81 \\
\hline Cropland & 88 & 81 & 19 & 12 & 54 \\
\hline Bushland & 90 & 71 & 29 & 10 & 66 \\
\hline Bare land & 32 & 100 & 0 & 68 & 8 \\
\hline Total & & & & & 253 \\
\hline Overall accuracy (\%) & $\mathbf{8 1}$ & & & & \\
\hline Kappa coefficient & $\mathbf{0 . 7 6}$ & & & & \\
\hline
\end{tabular}

Table VII.

Accuracy assessment of the 1990 classification.

\begin{tabular}{|l|c|c|c|c|c|}
\hline Class & $\begin{array}{c}\text { Producer } \\
\text { accuracy (\%) }\end{array}$ & $\begin{array}{c}\text { User } \\
\text { accuracy (\%) }\end{array}$ & $\begin{array}{c}\text { Commission } \\
\text { error (\%) }\end{array}$ & $\begin{array}{c}\text { Omission } \\
\text { error (\%) }\end{array}$ & $\begin{array}{c}\text { Reference } \\
\text { points }\end{array}$ \\
\hline Bare land & 50 & 83 & 17 & 50 & 12 \\
\hline Bushland & 66 & 57 & 43 & 34 & 44 \\
\hline Cropland & 74 & 82 & 18 & 26 & 28 \\
\hline Forest land & 86 & 74 & 26 & 14 & 69 \\
\hline Grassland & 60 & 64 & 36 & 40 & 14 \\
\hline Settlement & 63 & 100 & 0 & 38 & 5 \\
\hline Wetland & 93 & 100 & 0 & 7 & 27 \\
\hline Total & & & & & \\
\hline Overall accuracy (\%) & $\mathbf{7 5}$ & & & & \\
\hline Kappa coefficient & $\mathbf{0 . 6 9}$ & & & & \\
\hline
\end{tabular}

Table VIII.

Confusion matrix table for the 2016 classification.

\begin{tabular}{|c|c|c|c|c|c|c|c|c|}
\hline \multirow[t]{2}{*}{ Class } & \multirow[b]{2}{*}{ Grassland } & \multirow[b]{2}{*}{ Bushland } & \multirow[b]{2}{*}{ Forest land } & \multicolumn{2}{|c|}{ Ground Truth (pixels) } & \multirow[b]{2}{*}{ Cropland } & \multirow[b]{2}{*}{ Bare land } & \multirow[b]{2}{*}{ Tota } \\
\hline & & & & Wetland & Settlement & & & \\
\hline Unclassified & 0 & 0 & 0 & 6 & 0 & 0 & 0 & 6 \\
\hline Grassland & 20 & 0 & 1 & 0 & 0 & 0 & 16 & 37 \\
\hline Bushland & 9 & 91 & 8 & 0 & 0 & 4 & 21 & 133 \\
\hline Forest land & 0 & 15 & 141 & 0 & 0 & 5 & 1 & 162 \\
\hline Wetland & 0 & 0 & 0 & 33 & 0 & 0 & 0 & 33 \\
\hline Settlement & 0 & 0 & 0 & 0 & 26 & 0 & 0 & 26 \\
\hline Cropland & 6 & 2 & 6 & 0 & 4 & 154 & 6 & 178 \\
\hline Bare land & 1 & 0 & 0 & 0 & 0 & 0 & 15 & 16 \\
\hline Total & 36 & 108 & 156 & 39 & 30 & 163 & 59 & 591 \\
\hline
\end{tabular}


Table IX.

Confusion matrix table for the 2009 classification.

\begin{tabular}{|c|c|c|c|c|c|c|c|c|}
\hline \multirow[t]{2}{*}{ Class } & \multirow[b]{2}{*}{ Grassland } & \multirow[b]{2}{*}{ Bushland } & \multirow[b]{2}{*}{ Forest land } & \multicolumn{2}{|c|}{ Ground Truth (pixels) } & \multirow[b]{2}{*}{ Cropland } & \multirow[b]{2}{*}{ Bare land } & \multirow[b]{2}{*}{ Total } \\
\hline & & & & Wetland & Settlement & & & \\
\hline Unclassified & 0 & 0 & 0 & 2 & 1 & 8 & 0 & 11 \\
\hline Settlement & 7 & 0 & 0 & 0 & 0 & 0 & 0 & 7 \\
\hline Grassland & 0 & 26 & 0 & 0 & 0 & 0 & 3 & 29 \\
\hline Bushland & 0 & 1 & 40 & 1 & 3 & 1 & 5 & 51 \\
\hline Wetland & 0 & 0 & 0 & 32 & 0 & 0 & 0 & 32 \\
\hline Forest land & 0 & 1 & 17 & 0 & 59 & 4 & 2 & 83 \\
\hline Cropland & 3 & 0 & 1 & 0 & 4 & 37 & 1 & 46 \\
\hline Bare land & 0 & 0 & 0 & 0 & 1 & 0 & 5 & 6 \\
\hline Total & 10 & 28 & 58 & 35 & 68 & 50 & 16 & 265 \\
\hline
\end{tabular}

Table X.

Confusion matrix table for the 2000 classification.

\begin{tabular}{|c|c|c|c|c|c|c|c|c|}
\hline \multirow[t]{2}{*}{ Class } & \multirow[b]{2}{*}{ Grassland } & \multirow[b]{2}{*}{ Bushland } & \multirow[b]{2}{*}{ Forest land } & \multicolumn{2}{|c|}{ Ground Truth (pixels) } & \multirow[b]{2}{*}{ Cropland } & \multirow[b]{2}{*}{ Bare land } & \multirow[b]{2}{*}{ Total } \\
\hline & & & & Wetland & Settlement & & & \\
\hline Unclassified & 0 & 0 & 0 & 0 & 1 & 0 & 0 & 1 \\
\hline Wetland & 9 & 0 & 0 & 0 & 0 & 0 & 0 & 9 \\
\hline Settlement & 0 & 13 & 0 & 0 & 1 & 0 & 0 & 14 \\
\hline Grassland & 0 & 0 & 13 & 0 & 0 & 1 & 6 & 20 \\
\hline Forest land & 1 & 1 & 0 & 71 & 3 & 4 & 1 & 81 \\
\hline Cropland & 1 & 1 & 5 & 1 & 44 & 0 & 2 & 54 \\
\hline Bushland & 0 & 0 & 2 & 8 & 1 & 47 & 8 & 66 \\
\hline Bare land & 0 & 0 & 0 & 0 & 0 & 0 & 8 & 8 \\
\hline Total & 11 & 15 & 20 & 80 & 50 & 52 & 25 & 253 \\
\hline
\end{tabular}

Table XI.

Confusion matrix table for the 1990 classification.

\begin{tabular}{|c|c|c|c|c|c|c|c|c|}
\hline \multirow[t]{2}{*}{ Class } & & & & \multicolumn{2}{|c|}{ Ground Truth (pixels) } & \multirow{3}{*}{$\begin{array}{c}\text { Cropland } \\
0\end{array}$} & \multirow{3}{*}{$\begin{array}{c}\text { Bare land } \\
1\end{array}$} & \multirow{3}{*}{$\begin{array}{r}\text { Total } \\
1\end{array}$} \\
\hline & Grassland & Bushland & Forest land & Wetland & Settlement & & & \\
\hline Unclassified & 0 & 0 & 0 & 0 & 0 & & & \\
\hline Bare land & 10 & 0 & 0 & 1 & 1 & 0 & 0 & 12 \\
\hline Bushland & 5 & 25 & 3 & 5 & 4 & 1 & 1 & 44 \\
\hline Cropland & 0 & 0 & 23 & 2 & 1 & 2 & 0 & 28 \\
\hline Forest land & 1 & 13 & 4 & 51 & 0 & 0 & 0 & 69 \\
\hline Grassland & 4 & 0 & 1 & 0 & 9 & 0 & 0 & 14 \\
\hline Settlement & 0 & 0 & 0 & 0 & 0 & 5 & 0 & 5 \\
\hline Wetland & 0 & 0 & 0 & 0 & 0 & 0 & 27 & 27 \\
\hline Total & 20 & 38 & 31 & 59 & 15 & 8 & 29 & 200 \\
\hline
\end{tabular}


the findings by Verlinden and Laamanen (2006) that Landsat imagery is suitable for estimating tree cover and biomass at regional level in northern Namibia. Furthermore, forest land appeared to be relatively unaffected by forest fires as field observations and image analysis showed. Indeed, areas with high NDVI values remained unchanged compared to areas with low NDVI values. This is in line with the findings by Stellmes et al. (2013) who concluded that wild fires mostly affect grassland and other vegetation types but not forest crowns. However, findings by De Cauwer et al. (2016) indicated that higher fire frequency directly results in early tree mortality, which may result in a degradation of the forest landscape. It is possible that this is happening but the reduction in crown cover is not large enough to drop below $10 \%$ and hence the land remains classified as open forest.

The object-based method took into consideration the spectral signatures of crop fields, as well as their shape and size. The use of the "rectangular fit" and "elliptic fit" tools enabled to map the rectangular shapes of crop fields on subsistence farms and the circular shapes of irrigated crop fields on commercial farms. This may be attributed to the high producer accuracy of $95 \%$. Cropland had high NDVI values especially on irrigated commercial farms. Using these tools successfully avoided the challenge of discriminating between forestland and cropland based on their NDVI values. The use of NIR mean band values to classify wetland resulted in a high producer accuracy of $85 \%$.

Although a direct comparison between object and pixel-based approaches was not within the scope of this study, studies comparing the two approaches have been conducted before. For instance, Esetlili et al. (2018) reported that object-based approaches produced superior overall accuracy and Kappa statistics compared to pixel-based methods in crop mapping. Jawak et al. (2018) obtained overall accuracy of $90 \%$ and a Kappa value of 0.88 for object-based classification compared to an overall accuracy of $79 \%$ and Kappa value of 0.75 for pixel-based methods. Accurate and reliable estimate of land cover features is essential as this underpins policy formulation and sustainable land management strategies.

\section{Land cover changes}

In the 1990-2000 epoch, considerable amount of forest land was converted to cropland. This may be attributed to the fact that since Namibia gained independence in 1990, green scheme farms such as Mashare, Uvhungu vhungu, Shitemo have been established in Kavango East with an aim of ensuring food security in the country (MAWF, 2008). The present study found that cleared land increased between 1990 and 2009 but reduced in 2016 . The increase in cleared land corroborates the findings by Mendelsohn (2009) who reported an increase in cleared land between 1943 and 1996 in the former Kavango region. The largest conversion from forest land to cropland was observed in the 2000-2009 epoch. This is contrary to the findings by Kamwi et al. (2015), who reported a significant increase in forest land and a decrease in cropland from 1991 to 2010 in the Zambezi region. These differences could be due to the fact that, large portions of the
Zambezi region have been declared as protected land whereby land clearing is prohibited by the state. As such, forests have mostly remained undisturbed. Furthermore, socio-economic conditions which are regarded as one of the drivers of land cover change, are different between the two regions. The 2000-2009 epoch coincided with the launch of the Ndonga Linena green scheme project by the Ministry of Agriculture, Water and Forestry (MAWF) where 1,000 ha of forest land was cleared to establish a commercial farm (MAWF, 2008). However, the clearing of forests decreased in the 20092016 epoch. A possible explanation for this decrease may be that people began to view economic opportunities such as employment being far more attractive compared to subsistence farming (NSA, 2012). Furthermore, the end of the civil war in Angola may have contributed to the decrease in cleared land as people returned to southern Angola. This is in line with the findings by Röder et al. (2015), who reported that a substantial increase in the conversion of woodland to cleared land is anticipated in Southern Angola as repatriates return from Namibia.

Fire scars, seasonality effects and rainfall variability complicated interpretation on Landsat and other imagery used as reference. Despite conducting comprehensive field work, a large portion of the study area was not visited due to inaccessibility to the sampling sites. Some of the Google Earth imagery used to complement the control points were outdated. For instance, in the southern parts of the study area, the available images were for the year 2012 whereas the 2016 reference points were collected. In addition, the required months were either May or June but some of the available Google Earth imagery were captured between September and November resulting in seasonality effects on the data collected (photo 4). This could be improved by adopting a community-based data collection approach were community members collect ground truth data (De Vries et al., 2016). Also, rainfall variation between the years may have triggered the detection of false forest regrowth and false deforestation. All these elements have resulted in inaccuracies for some of the reference points.

Classifying grassland and bare land was a challenge as evidenced by their low producer accuracy values. Despite using the NDVI and NDBI ratios to classify grassland and bare land, the two classes appeared identical. By using imagery for May-June period, early season fires might have cleared dry grasses to produce bare land. Discriminating identical classes on a $30 \mathrm{~m}$ Landsat imagery proved difficult. In addition, there was a challenge in discriminating settlements from bare land as they have a related spectral signature. Despite incidences of logging observed when field work was conducted, the classified maps and the changed polygons did not reveal the areas where such logging was observed. This corroborates the findings by Asner et al. (2002) that Landsat imagery has challenges in quantifying incidences of selective forest logging. Satellite Imagery with higher spatial resolution such as Sentinel 2 may exploit the advantages of object-based image analysis. Despite the challenging environmental conditions which influences the accuracy of the land cover products, the results produced shows that the object-based approach can be used for long term monitoring of land cover change. 


\section{Conclusion}

A multi-date object-based image analysis was applied to study the dynamics of land cover change in the dry tropical forests of the Kavango East Region - Northeastern Namibia. The results show that the methods applied offer a viable alternative to pixel approaches due to the fact that it is based on two components before the production of the land cover maps. First, by detecting and understanding the changed polygons, second, by mapping unchanged polygons based on mean band values. This approach avoids propagating errors from one study period to another, while simultaneously, land cover change host spots are identified and mapped accurately. The overall accuracy results ranged between $75 \%$ and $81 \%$ for the years under investigation.

Applied on sets of four Landsat images spanning from 1990 to 2016, it was discovered that large areas of the Kavango East region remained intact. This was mostly observed in the southern, western and eastern parts of the region where population density is low and access via road is limited. Most land cover changes were observed along the Okavango river and the Trans-Caprivi highway. The most common land conversion was from forest to cropland for all epochs. In 1990 forest covered $58 \%$ of the land but by 2016 , this extent was reduced to $54 \%$. In the meantime, cropland covering $3 \%$ of the study area in 1990 doubled to reach $6 \%$ by 2016 .

The dry environmental conditions in Namibia makes satellite based remote sensing analysis difficult. Variations

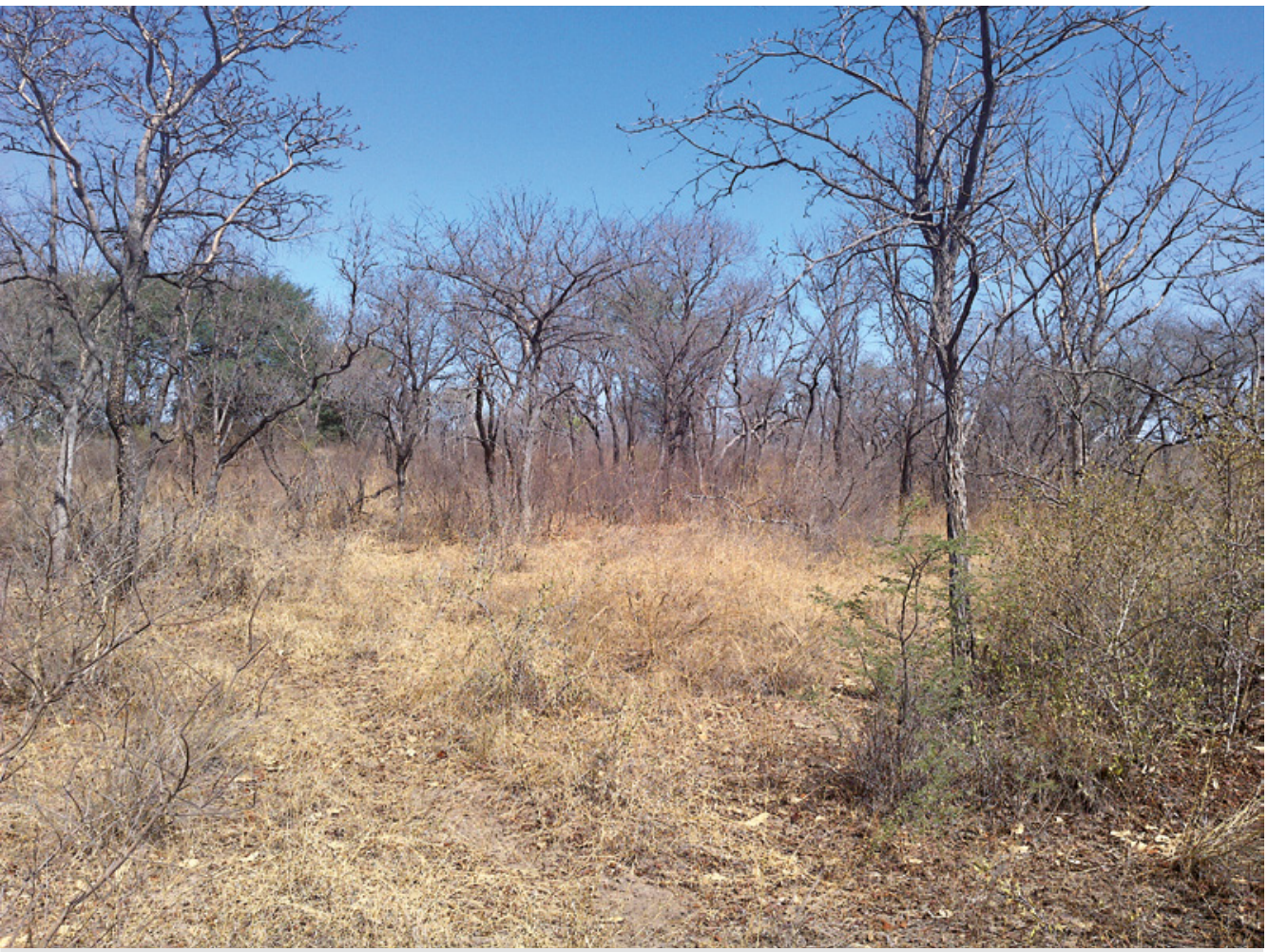

Photo 4.

Vegetation after the dry winter season. Seasonality effects had an impact on the accuracy of the maps produced.

Photo E. Muhoko. in rainfall patterns, seasonality effects and fire scars contributed to false detections of forest loss and forest growth. The use of an object-based approach appeared promising to handling the complexity of the landscape. However, this did not solve all issues on mixed land cover classes. Reference datasets can be improved by involving community members to collect validation datasets on observed land cover changes over time. This may lead to improvements in the accuracy of the land cover products. In the future, higher spatial resolution imagery should be used to quantify forest logging. The present study employed a new approach for land cover change mapping in the dry tropical forests of North-eastern Namibia. In this regard, in order to improve mapping accuracy in areas under similar environmental and biophysical conditions, the method can be used for long term monitoring purposes.

\section{Acknowledgements}

The authors would like to thank the Southern African Science Service Centre for Climate Change and Adaptive Land Management (SASSCAL) task 303, and the Directorate of Forestry in the Ministry of Environment, Forestry and Tourism (MEFT) for the financial support.

\section{References}

Asner G., Keller M., Pereira R., Zweede J., 2002. Remote sensing of selective logging in Amazonia assessing limitations based on detailed field observations, Landsat ETM+, and textural analysis. Remote Sensing of Environment, 80: 483-496. https://doi.org/10.1016/ s0034-4257(01)00326-1

Campbell J., Wynne R., 2011. Introduction to Remote Sensing (5th ed.). New York, USA, The Guilford Press, 305 p.

Cracknell A. P., 2001. The exciting and totally unanticipated success of the AVHRR in applications for which it was never intended. Advances in Space Research, 28 (1): 233-240. https:// doi.org/10.1016/s02731177(01)00349-0 
De Cauwer V., Geldenhuys C. J., Aerts R., Kabajani M., Muys B., 2016. Patterns of forest composition and their long-term environmental drivers in the tropical dry forest transition zone of southern Africa. Forest Ecosystems, 3 (1): 23. https://doi.org/10.1186/s40663-016-0080-9

De Cauwer V., 2015. Towards estimation of growing stock for the timber tree Pterocarpus angolensis in Namibia. Presented at the DAAD World Forestry Congress Workshop Bridging the Gap between Forest Information Needs and Forest Inventory Capacity, 7-12 September, Pietermaritzburg, South Africa.

Desclée B., Bogaert P., Defourny P., 2006. Forest change detection by statistical object-based method. Remote Sensing of Environment, 102 (1-2): 1-11. https://doi. org/10.1016/j.rse.2006.01.013

De Vries B., Pratihast A., Verbesselt J., Kooistra L., Herold M., 2016. Characterizing Forest Change Using CommunityBased Monitoring Data and Landsat Time Series. PLoS ONE, 11 (3): e0147121. https://doi.org/10.1371/journal. pone. 0147121

Directorate of Forestry, 2013. Forest inventory data, 20022013. Microsoft Excel data file. Windhoek, Namibia, Ministry of Agriculture, Water and Forestry.

Directorate of Forestry, 2012. Community Forestry in Namibia. Windhoek, Namibia, Ministry of Agriculture, Water and Forestry. https://doi.org/10.1371/journal.pone.0147121

Dirzo R., Young H. S., Galletti Y. M., Ceballos G., Nick J. B., Collen B., 2014. Defaunation in the Anthropocene. Science, 345: 401-406. https://doi.org/10.1126/science.1251817

Ernst C., Verhegghen A., Bodart C., Mayaux P., de Wasseige C., Bararwandika A., et al., 2010. Congo basin forest cover change estimate for 1990, 2000 and 2005 by Landsat interpretation using an automated object-based processing chain. International Archives of the Photogrammetry, Remote Sensing and Spatial Information Sciences, 38 (4).

Esetlili M. T., Balcik F. B., Şanli F. B., Üstüner M., Kalkan K., Göksel C., et al., 2018. Comparison of Object and Pixel-Based Classifications for Mapping Crops Using Rapideye Imagery: A Case Study of Menemen Plain, Turkey. International Journal of Environment and Geoinformatics, 5 (2): 231-243. https:// doi.org/10.30897/ijegeo.442002

FAO, 2001. Nutrition Country Profiles - Namibia. Rome, Italy, FAO. http://www.fao.org/tempref/AG/agn/nutrition/ncp/ nam.pdf

Flood N., 2014. Continuity of reflectance data between Landsat-7 ETM+ and Landsat-8 OLI, for both Ttop-ofatmosphere and surface reflectance: A study in the Australian landscape. Remote Sensing, 6 (9): 7952-7970. https://doi.org/10.3390/rs6097952

IPCC, 2003. Good practice guidance for land use, land-use change and forestry. In: Penman J., Gytarsky M., Hiraishi T., Krug T., Kruger D., Pipatti R., etal. (eds). The Intergovernmental Panel on Climate Change. Hayama, Kanagawa, Japan. https://doi.org/10.1007/springerreference_28950
Jawak S. D., Wankhede S. F., Luis A. J., 2018. Comparison of Pixel and Object-Based Classification Techniques for Glacier Facies Extraction. The International Archives of the Photogrammetry, Remote Sensing and Spatial Information Sciences, 42 (5). https://doi.org/10.5194/isprs-archivesXLII-5-543-2018

Juniati E., Arrofigoh E. N., 2017. Comparison of Pixel-Based and Object-Based Classification Using Parameters and Non-Parameters Approach for The Pattern Consistency of Multi Scale Land Cover. The International Archives of the Photogrammetry, Remote Sensing and Spatial Information Sciences, 42 (2)/W7. https://doi.org/10.5194/isprsarchives-xlii-2-w7-765-2017

Kamwi J. M., Cho M., Kaetsch C., Manda S., Graz F., Chirwa P., 2018. Assessing the spatial drivers of land use and land cover change in the protected and communal areas of the Zambezi Region, Namibia. Land, 7 (4): 131. https://doi. org/10.3390/land7040131

Kamwi J. M., Chirwa P. W. C., Manda S. O. M., Graz P. F., Kätsch C., 2015. Livelihoods, land use and land cover change in the Zambezi Region, Namibia. Population and Environment, 37 (2): 207-230. https://doi.org/10.1007/ s11111-015-0239-2

Mango L. M., Melesse A. M., McClain M. E., Gann D., Setegn G., 2011. Land use and climate change impacts on the hydrology of the upper Mara River Basin, Kenya: results of a modeling study to support better resource management. Hydrology and Earth System Sciences, 15: 2245-2258. https://doi.org/10.5194/hess-15-2245-2011

MAWF (Ministry of Agriculture, Water and Forestry), 2008. Green Schemes farms of Namibia (No. 1). Windhoek, Namibia.

Mendelsohn J., Jarvis A., Roberts C., Robertson T., 2002. Atlas of Namibia. A Portrait of the Land and its People. Windhoek, Namibia, Ministry of Environment and Tourism. https://onlinelibrary.wiley.com/doi/abs/10.1002/ $\underline{\text { mmnz.20040800111 }}$

Mendelsohn J., 2009. Land use in Kavango: Past, Present and Future. OKACOM. Research and information Services of Namibia. Retrieved from http://www.the-eis.com/data/ literature/Mendelsohn Land\%20use\%200Kavango.pdf

MLR (Ministry of Land Reform), 2015. Integrated Regional Land Use Plan for the Kavango East Region Baseline Report (Volume 1). Windhoek, Namibia.

Myneni R., Hall F., Sellers P., Marshak A., 1995. The interpretation of spectral vegetation indexes. TIEE Transactions on Geoscience and Remote Sensing, 33 (2): 481-486. https://doi.org/10.1109/36.377948

Namibia Meteorological Service, 2014. Daily rainfall entry for seasonal monitoring and production of climate bulletin. Microsoft Excel data file. Windhoek, Namibia. 
NBSAP, 2014. Namibia's Second National Biodiversity Strategy Action Plan 2013-2022. http://www.met.gov. na/files/files/Namibia\%E2\%80\%99s\%20Second\%20 National $\% 20$ Biodiversity $\% 20$ Strategy $\% 20$ and $\% 20$ Action $\% 20$ Plan $\% 20($ NBSAP\%202)\%20\%202013\%20-\%20 2022.pdf

NSA (Namibia Statistics Agency), 2012. Namibia Population and Housing Main Report. Windhoek, Namibia.

Pröpper M., Gröngröft A., Falk T., Eschenbach A., Fox T., Gessner U., et al., 2010. Causes and perspectives of land-cover change through expanding cultivation in Kavango. Biodiversity in Southern Africa, 3: 1-31. http:// researchspace.csir.co.za/dspace/handle/10204/4831

Pröpper M., Vollan B., 2013. Beyond Awareness and SelfGovernance: Approaching Kavango Timber Users' RealLife Choices. Land, 2: 392-418. https://doi.org/10.3390/ land2030392

Röder A., Pröpper M., Stellmes M., Schneibel A., Hill J., 2015. Assessing urban growth and rural land use transformations in a cross-border situation in Northern Namibia and Southern Angola. Land Use Policy, 42 (2015): 340-354. https://doi.org/10.1016/j.landusepol.2014.08.008

Schultz M., Shapiro A., Clevers J. G. P. W., Beech C., Herold M., 2018. Forest Cover and Vegetation Degradation Detection in the Kavango Zambezi Transfrontier Conservation Area Using BFAST Monitor. Remote Sensing, 10 (11): 1850. https://doi. org/10.3390/rs10111850

Stellmes M., Frantz D., Finckh M., Revermann R., 2013. Fire frequency, fire seasonality and fire intensity within the Okavango region derived from MODIS fire products. Biodiversity and Ecology, 5: 351-362. https://doi.org/10.7809/b-e.00288

Trimble, 2014. eCognition $®$ Developer Reference Book. Munich, Germany, Trimble Germany GmbH, 258 p.

Tucker C. J., Pinzon J. E., Brown M. E., Slayback D. A., Pak E. W., Mahoney R., et al., 2005. An extended AVHRR 8-km NDVI dataset compatible with MODIS and SPOT vegetation NDVI data. International Journal of Remote Sensing, 26 (20): 4485 4498. https://doi.org/10.1080/01431160500168686

Verhegghen A., Ernst C., Defourny P., Beuchle R., 2010. Automated land cover mapping and independent change detection in tropical forest using multi-temporal highresolution data set. The International Archives of the Photogrammetry, Remote Sensing and Spatial Information Sciences, 38 (4).

Verlinden A., Laamanen R., 2006. Modeling woody vegetation resources using Landsat TM imagery in northern Namibia. The Southern African Forestry Journal, 207 (1): 27-39. https://doi.org/10.2989/10295920609505250
Viera A. J., Garret J. M., 2005. Understanding Interobserver Agreement: The Kappa Statistic. Family Medicine, 37: 360363. https://www.ncbi.nlm.nih.gov/pubmed/15883903

Wingate V., Phinn S., Kuhn N., Bloemertz L., Dhanjal-Adams K., 2016. Mapping Decadal Land Cover Changes in the Woodlands of North Eastern Namibia from 1975 to 2014 Using the Landsat Satellite Archived Data. Remote Sensing, 8 (8): 681. https://doi.org/10.3390/rs8080681

Zha Y., Gao J., Ni S., 2003. Use of normalized difference built-up index in automatically mapping urban areas from TM imagery, International Journal of Remote Sensing, 24 (3): 583-594. https://doi.org/10.1080/01431160304987

\section{Muhoko et al. - Contribution des auteurs}

\section{CONTRIBUTOR ROLE CONTRIBUTOR NAMES}

\begin{tabular}{l|l|}
\hline Conceptualization & E. Muhoko \\
\hline Data Curation & E. Muhoko \\
\hline Formal Analysis & $\begin{array}{l}\text { E. Muhoko, C. de Wasseige, } \\
\text { V. De Cauwer }\end{array}$ \\
\hline Funding Acquisition & E. Muhoko \\
\hline Investigation & E. Muhoko \\
\hline Methodology & E. Muhoko, C. de Wasseige \\
\hline Project Administration & S. Moukrim, S. Lahssini \\
\hline Resources & E. Muhoko, C. de Wasseige, \\
\hline Software & E. Muhoko Cauwer \\
\hline Supervision & E. Muhoko, C. de Wasseige, \\
\hline V. De Cauwer \\
\hline Validation & E. Muhoko, C. de Wasseige, \\
\hline Visualization & V. De Cauwer \\
\hline $\begin{array}{l}\text { Writing - Original } \\
\text { Draft Preparation }\end{array}$ & E. Muhoko \\
\hline Writing - Review \& & E. Muhoko \\
\hline Editing & E. Muhoko, C. de Wasseige, \\
\hline
\end{tabular}

Bois et Forêts des Tropiques - Revue scientifique du Cirad
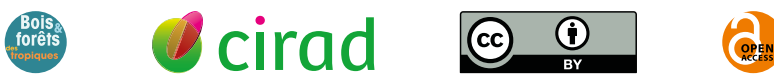

Cirad - Campus international de Baillarguet, 34398 Montpellier Cedex 5, France - Contact : bft@cirad.fr - ISSN : L-0006-579X 